\title{
Endopolygalacturonase Is Not Required for Pathogenicity of Cochliobolus carbonum on Maize
}

\author{
John S. Scott-Craig, ${ }^{a}$ Daniel G. Panaccione, ${ }^{a}$ Felice Cervone, ${ }^{b}$ and Jonathan D. Walton ${ }^{a, 1}$ \\ a Department of Energy Plant Research Laboratory and Department of Botany and Plant Pathology, Michigan State \\ University, East Lansing, Michigan 48824-1312 \\ 'Dipartimento di Biologia Vegetale, Università di Roma "La Sapienza," Piazzale A. Moro, 00100 Rome, Italy
}

\begin{abstract}
A gene (PGN1) encoding extracellular endopolygalacturonase was isolated from the fungal maize pathogen Cochliobolus carbonum race 1. A probe was synthesized by polymerase chain reaction using oligonucleotides based on the endopolygalacturonase amino acid sequence. Genomic and CDNA copies of the gene were isolated and sequenced. The corresponding mRNA was present in $C$. carbonum grown on pectin but not on sucrose as carbon source. The single copy of PGN1 in $C$. carbonum was disrupted by homologous integration of a plasmid containing an internal fragment of the gene. Polygalacturonase activity in one transformant chosen for further analysis was $10 \%$ or $35 \%$ of the wild-type activity based on viscometric or reducing sugar assays, respectively. End product analysis indicated that the residual activity in the mutant was due to an exopolygalacturonase. Pathogenicity on maize of the mutant lacking endopolygalacturonase activity was qualitatively indistinguishable from the wild-type strain, indicating that in this disease interaction endopolygalacturonase is not required. Either pectin degradation is not critical to this interaction or exopolygalacturonase alone is sufficient.
\end{abstract}

\section{INTRODUCTION}

The plant cell wall is a major element in the environment of plant pathogens as both a barrier to infection and a source of metabolizable substrates. Most if not all cellular pathogens as well as many nonpathogenic microorganisms possess an array of enzymes that can degrade plant cell wall polymers. The role played by these cell walldegrading enzymes in establishment of disease and in symptom development has been the subject of extensive research (Bateman and Basham, 1976; Cooper, 1984; Hahn et al., 1989).

Of the more than 20 cell wall-degrading enzymes known to be produced by pathogens, most attention has focused on those that depolymerize pectin: the exo- and endoforms of polygalacturonase (PG), the exo- and endo- forms of pectic lyase (PL), and pectin methylesterase (PME). Pectinases are often the first cell wall-degrading enzymes produced by pathogens when cultured on purified plant cell walls and during infection (English et al., 1972; Anderson, 1978). Purified pectinases can cause tissue maceration, a major symptom of some plant diseases (Collmer and Keen, 1986). In vitro, endoPG must act on isolated cell walls before other cell wall-degrading enzymes can act (Karr and Albersheim, 1970). In addition, PG and PL can elicit the biosynthesis of phytoalexins and other defense responses by way of the production of elicitor-active oli-

\footnotetext{
${ }^{1}$ To whom correspondence should be addressed.
}

gogalacturonides (Lee and West, 1981; Bishop et al., 1984; Davis et al., 1984; Cervone et al., 1987). Plants contain proteins, called PG-inhibitor proteins, that modulate the activity of endoPG and thereby increase its elicitor activity (Cervone et al., 1989).

A number of bacterial pectinase genes have been cloned and selectively mutated to analyze their contribution to disease. A strain of Erwinia chrysanthemi lacking all four PL genes was still able to grow on polygalacturonic acid (PGA) as sole carbon source and to cause limited maceration of plant tissue (Ried and Colimer, 1988). The gene for one of the three PLs of Xanthomanas campestris pv campestris has been cloned; its specific deletion had no effect on disease development on turnip (Dow et al., 1989). The gene encoding PME has been cloned from $E$. chrysanthemi, and a strain with a disrupted PME gene was noninvasive (Plastow, 1988; Boccara and Chatain, 1989). Deletion of one of two genes encoding endoPG in Pseudomonas solanacearum reduced virulence on tomato by approximately 50\% (Huang and Schell, 1990).

There have been fewer classical and molecular genetic studies of fungal pectinases. Genes encoding pectic lyase have been cloned from Aspergillus nidulans (Dean and Timberlake, 1989) and Aspergillus niger (Gysler et al., 1990). Mann (1962) used UV irradiation to produce mutants of Fusarium oxysoporum $f \mathrm{sp}$ /ycopersici lacking $P G$ and PME activity. The mutants were still pathogenic on 
1 AACCTTCTCAGGGCCCGAGACCCTCAGCGGCCCCTCTCACACTCCCTCCCCCC TICATAT 61 AGATTAAGCTAGTTGTTCCATCAATCGGTCGTACTCGGCAGTGTAAACACGCAACCCGTG 121 TTCGGCATCCACGTGCCGACTAGGGCGCTACGCCACAGCAGCGCCACGC TICTGTATCCC 181 GICTITGACCAAAACATGTTTCACCATGCCGC TGTAATTTCGTTTCAGCATGGGTCGGCA 241 CACCCATTGCCGGTTTGTTTTGCAAATCTGAGATGAGATATTGTAAGCTCCGCCGAACGG 301 CTCGCAGCGC TGATGGCTGACACAGTGCAAAGGATAAATACTAAGATACGTTCTAAGACC 361 CAAATCTTCCAGAATACGAAGATACAATCTACGAACGTTCCGCAACGCGGAGAAATCGAT 421 CAGGTGGATCCTCCAATGCTTGTCATTCCGGTTCITTACTACTCATGTCCATCCAAAACG 481 TGGCCTAGGGCAGTGTCAAGCATTGCCTAGAGCGACAAGCCTCCGAGATTCTAGAGCTAG 541 AGTTAGCTTAACACGACCTGTGGGGAGCCAGTCTCTACTGCCCCTCATGTTGCOCC 601 CTIGTATAGTACTGAGGTTCCTCCAGTTCTACTGCCCTCATGTTTGGGGCC A 721 AGCAAAATGGTCGCATATGCTCTCACTTCGATGCTTCTGAGCGCTGGTGCGCTCGTCGCT 781 GCCGCCCCATCAGGTCTTGATGCCCGCGATGGC O1:GCAC I

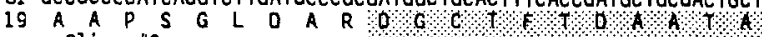
0 i igo 12 341 ATCAACAACAAGGCCTCTTGCAGCAACATTGTCATCAGCGGCATGACAGTTCCTGCTGGT 39 K N K A S C S N I V I S G M T V P A G 901 RECACCCTGGACCTCACGGGCTTGAAGTCCGGTGCCACCGTCACCTTCCAGGGCACAACG 961 ACCTTTGGATACAAGGAGTGGGAAGGTCCTCTCATCTCCGTCTCCGGAACTAACATCAAA 79 T F G Y K E K E G P L I S Y S G T N I K

1021 GTGGTGGGTGCCTCCGGCCACACCATTGATGCCGCTGGTCAGAAGTGGTGGGACGGAAAG $99 \vee V G A$ S G H T I D A A G Q K W W D G K

1081 GGATCCAACGGCGGCAAGACCAAGCCCAAGGTAAGCGATGAGTTCACTGAAAGTIAATCT 119 G S N G G K T K P K

1141 GAACTGTAGTCTGACTAACCAATCCAGTTCTTCTACGCTCACTCCCTGACCACATCCTCA 129 F F Y A H S L T T S S

1201 ATCAGCGGACTCAACATCAAGAACACTCCCGTCCAGGCCTTCTCCATCAACGGTGTCACC

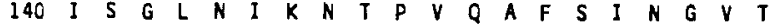
1261 GGCTTGACTCTTGACCGCATCACCATCGACAACTCTGCAGGCGACTCAGCCGGCGCCCAC 160 O L L T L D R R I T I I D

1321 AACACCGACGCCTTCGACATTGGCAGCTCCAGCGGCATCACCATCTCCAACGCCAACATC 180 N T O A F D I G S S S G I T I S N A N I

1381 AagaACCAAGACGACTGCGTCGCCATCAACTCCGGCAGCGACATCCACGTCACAMACTGC $200 \mathrm{~K} N Q$ D D C V A I N S G S D I H V T N C 1441 CAGTGCTCCGGCGGCCACGGCGTCTCCATCGGCTCCGTTGGCGGCCGCAAGGACAACACC 220 O C S G G H G V S I G S V G G R K D N T 1501 GTCAAGGGCGTCGTCGTCAGCGGCACCACCATCGCCAACTCGGACAACGGCGTCCGCATC 240 V K G V V V S G T T I A N S D N G VR I 1561 AAGACCATCTCCGGCGCCACTGGCTCCGTCTCCGACATCACCTACGAAAACATCACCCTC

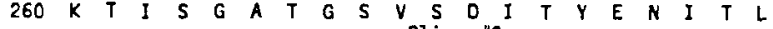
1621 AAGAACATCGCCAAGTACGGCATCG OICATCGAGCAGGACTACCTCAACGGCGGCCCAACT

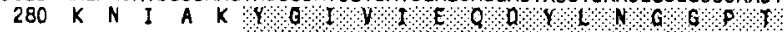
1681 GGCAAGCCCACCACTGGCGTCCCCATTACCGGTGTTACGCICAAGAACGTTGCCGGTAGC $300 \mathrm{~K}$ P ग T 6 V P I T G V T L K N V A G S 1741 GTTACTGGATCCGGCACCGAGATCTACGTCCTTTGCGGAAAGGGAAGCTGCTCCGGCTGG 320 V T G S G T E I Y V L C G K G S C S G W 1801 AACTGGTCCGGTGTCAGCAITACCGGTGGAAAGAAGRGCT

340 N W G V S I T G G K K S S S C L N Y P

1861 TCTGGCGCTICTTGCTAAGCGGCCAAGGCAACTTITCTTGGGAGAGAGAAAAAGCGACTA 360 S G A S C -

1921 AGGTOTTCGGTCAGAGGCCGATGCCAACTACCCCTTAATTCTTCTTGTATATCTTCGTTT

1981 CATATATATATATATCTGAATGGCATAGAGTGCCTGGCTCAACTTTTCTTTTTGCTTCTC 1981 CATATATATATATATCTGAATGGCATAGAGTGCCTGGCTCAACTTTTCTTTITGCTTCTC

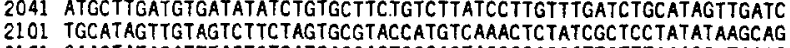
2161 CAACTATACATTIAGTCTCATCACCAGTCCCACTAGCGCACCGTTGTITAAACGATAAAG 2221 CATACGCTTACTTCACACGTACTAAAACAACACGCAGCCATACGATCCATTATATCCACA 2281 TTCGTTAACACATAAATACATCCGTTCCTCCACCACTCCCCATATATCACACCCTCTCCA 2341 ACCAAATCAACTTACTCTGATAATCCATTGGGTCCCACCTCACATTAATACCCCCATICA 2401 TATACGTCGCCCCACTATACGTCCCATTATCCAAATCATTCCTATACCTCGCCTTGGGAT 2461 CCAGACCCTGCAGCCTAACGGGGGGAGCAGCGGGTTTAATC TICATAGCC TGTTGGAACG 2521 CAAGACCGTGCTCTICGCGCATCCGGCCTCACAAACTGTACTOCGGGCCAATTCACT 2581 GTGCGGGGTGTGCGAGGCGGTAGAAGTCACCTGAAATGACGATGGGITTACCTCTITTG 2641 2701 GTTCAAGGCCGAAGGAGCCGCACATCATGGC TACGTGACCGCGGTATICGAAGC TGATGT 2761 TGCGGTTGGTGAGGTGGTTGGGG

Figure 1. Nucleotide and Deduced Amino Acid Sequences of the PGN1 Gene Encoding Endopolygalacturonase from C. carbonum. tomato but had reduced virulence. Howell (1975) concluded from mutagenesis studies with Sclerotinia fructigena that reduced virulence on apple fruits was positively correlated with lower $\alpha$-arabinosidase but not lower PME or PG activities. Puhalla and Howell (1975) isolated mutants of Verticillium dahliae showing no endoPG activity, which nonetheless induced only slightly delayed wilt symptoms in cotton. Durrands and Cooper (1988) obtained pectinase-deficient mutants of Verticillium albo-atrum that produced reduced or delayed symptoms but still colonized plants as effectively as the wild type. Interpretation of these mutagenesis studies is limited by the possibility that the mutant phenotype was due to more than one genetic lesion. The absence of a manipulable perfect state for these fungi precludes back-crossing each mutation into a wild-type background.

Recent progress in the manipulation of filamentous fungi by molecular genetic techniques has increased our ability to analyze these organisms. In particular, DNA-mediated transformation permits the reintroduction of altered copies of cloned genes, thereby allowing a definitive analysis of the role of particular gene products in disease (Yoder, 1988; Fincham, 1989).

This study was undertaken to determine the role of endoPG (poly- $\alpha$-1,4-galacturonide glycanohydrolase, EC 3.2.1.15) in infection of maize by the foliar pathogen Cochliobolus carbonum. We report the identification and cloning of the single gene (PGN1) encoding endoPG and the sequence of both genomic and CDNA clones. An internal fragment of the gene was used to construct a strain of the fungus lacking detectable endoPG activity in vitro; the pathogenic properties of this mutant are described.

\section{RESULTS}

\section{Polygalacturonase Gene Isolation}

Three degenerate oligonucleotides were synthesized based on two amino acid sequences shown in Figure 1 , one from the $\mathrm{N}$ terminus of the mature protein (Walton and Cervone, 1990) and the other from an internal tryptic peptide. Using the two flanking oligonucleotides (oligo 1 and oligo 3) as primers and genomic DNA from C. carbonum as template in polymerase chain reaction (PCR), an 854-bp fragment was amplified. On a DNA gel blot of size-separated PCR products, this fragment hybridized specifically to the internal oligonucleotide 2 (Figure 1). The

The shaded regions are the peptide sequences obtained from amino acid sequencing; the first one corresponds to the amino terminus of the mature protein. The regions used as a basis for synthesis of oligonucleotides 1,2 , and 3 are overlined. The Kpnl and Sacl restriction sites used to construct the disruption mutant are also overlined. An asterisk (") marks the polyadenylation site. 


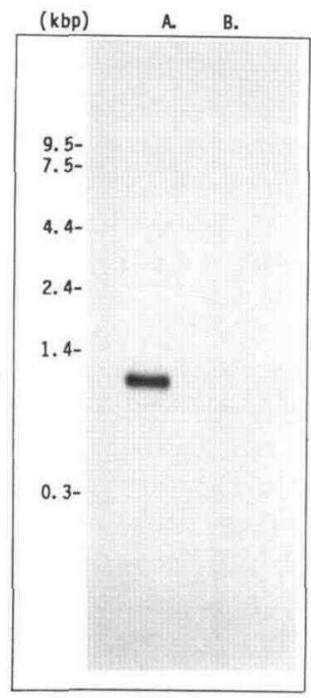

Figure 2. RNA Gel Blot Analysis of PG Expression.

Poly $(A)^{+}$RNA isolated from C. carbonum wild-type strain SB111, grown with either pectin (lane A) or sucrose (lane B) as the carbon source, was blotted and probed with a radiolabeled internal fragment of the PGN1 gene.

PCR product was cloned in a phagemid vector to create plasmid pCC33 and purified insert used to probe an RNA gel blot of poly $(A)^{+}$RNA isolated from $C$. carbonum grown with and without pectin in the medium. The RNA gel blot shown in Figure 2 demonstrates that the mRNA corresponding to the clone was induced only in the pectingrown culture. The same probe was used to screen a genomic library and a cDNA library, the latter made from poly $(A)^{+}$RNA from pectin-grown fungus. Several genomic clones were isolated and a 6.0-kb Sall fragment was subcloned and the sequence of both strands of a 2974-bp segment containing the putative PG gene was determined. The sequence of one strand of a 1262-bp cDNA clone was also determined and the two sequences were entirely colinear with the exception of a 57-bp intron occurring at nucleotides 1110 to 1167 (Figure 1). The intron contains conserved 5' (GTARGC) and 3' (YAG) splice junctions and internal consensus (RCTRAC) sequences (Orbach et al., 1986). The $3^{\prime}$ splice junction occurs only 4 bp after the internal consensus sequence (Figure 1). The polyadenylation site is $140 \mathrm{bp}$ downstream of the stop codon TAA; there is no obvious eukaryotic polyadenylation signal (Figure 1).

The DNA sequence of $P G N 1$ predicts a polypeptide of 33,992 $\mathrm{D}$ that is consistent with the size determined by gradient SDS-PAGE (Walton and Cervone, 1990). There is a putative transit peptide (von Heijne, 1986) of either 19 or 27 amino acids, based on the known $\mathrm{N}$-terminal amino acid of the mature protein (Walton and Cervone, 1990) and depending on which methionine residue (at nucleotide 727 or 751 ) is the true translational start site (Figure 1).

By computer analysis there were no significant nucleotide sequence similarities between the PGN1 gene in C. carbonum and endoPG genes from the bacteria Erwinia carotovora (Hinton et al., 1990; S.-P. Lei and G. Wilcox, personal communication) and Pseudomonas solanacearum (Huang and Schell, 1990), and the higher plant tomato (Grierson et al., 1986). As seen in Figure 3, however, several regions of significant similarity were identified at the amino acid level. All four endoPGs have 2 adjacent Trp residues at positions 114 and 115 (all positions refer to $C$. carbonum); additional highly conserved regions are from amino acids 203 to 208,224 to 231 , and 255 to 261 (Figure $3 \mathrm{~A}$ ). Moreover, two regions of amino acid sequence from $A$. niger endoPG had stretches of 12 and 5 amino acid residues that were identical in $C$. carbonum endoPG (Figure 3B). No significant similarity was found between $C$. carbonum endoPG and an exoPG from $E$. chrysanthemi (He and Collmer, 1990) or a PL from A. niger (Gysler et al., 1990) at either the nucleotide or the amino acid level.

\section{Transformation-Mediated Gene Disruption}

A Kpnl/Sacl fragment internal to the PGN1 gene open reading frame shown in Figure 4 was cloned in the Cochliobolus transformation vector pUCH1 (Schafer et al., 1989). The resulting construct, pCC38, was introduced into C. carbonum SB111 and transformants selected on hygromycin B. Whereas SB111 produced a large halo when grown on PGA agar, several transformants produced halos of reduced size and one transformant (named PG1) produced no halo, as can be seen in Figure 5. Figures $6 \mathrm{~A}$ and $6 \mathrm{~B}$ show a DNA gel blot analysis of DNA from the recipient strain and transformant PG1. The results are consistent with the plasmid integration event depicted in Figure 6D. PG1 was able to grow on pectin as sole carbon source and dry weights of mycelial mats grown on pectin, pectin $+0.2 \%$ sucrose, pectin $+2 \%$ sucrose, or $2 \%$ sucrose and harvested after 6 days were not statistically significantly different from those of mats produced by the wild-type strain (data not shown). When grown for 6 days on pectin $+2 \%$ sucrose, conditions that maximize endoPG titers (Walton and Cervone, 1990), culture filtrates of PG1 had 10 -fold fewer relative viscometric units of PG activity compared with SB111. In a reducing sugar assay (that does not distinguish between endoPG and exoPG), however, PG activity in culture filtrates of PG1 was reduced by only $65 \%$ to $75 \%$. These results suggested that the residual PG activity in PG1 was due to an exoPG. This was confirmed by end product analysis; culture filtrates of SB111 produced monomers, dimers, and larger oligomers of PGA, but PG1 produced only monomers.

$P G$ activities were purified in parallel from SB111 and PG1 by rotary evaporation, dialysis, and low-pressure 
A

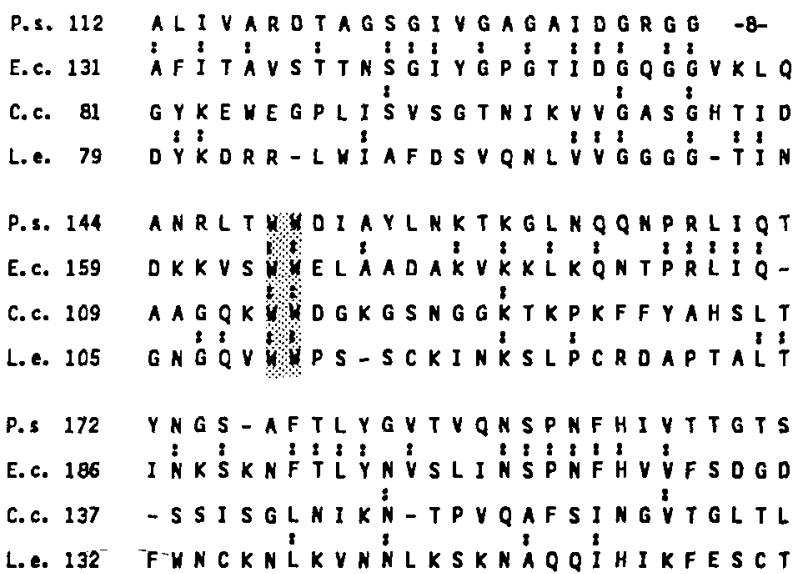

P.s. 199 GVTAKGIKIVTPSLAYAVAGYKCPSGS

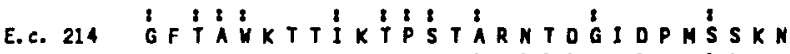
c.c. 164 DRITIDNSAGOSAGAHN C.c. 164 DRITIDNSAGOSAGAKRTEAFOIGSSSO L.e. 160 Y VASNLMI ASAKSPNTDGVHYSNTQY

P.s. $258-30-$ A Y SYI N T6OOOH WO YKASSGP- - TR

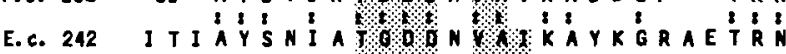

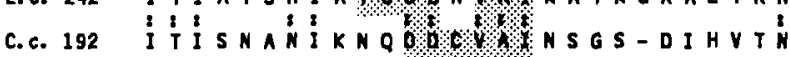

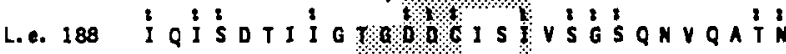

P.s. 281 LLFAHNHFYY GH6 L \$180SETNTG VSNML

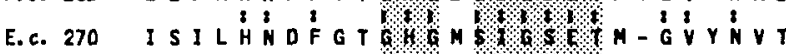

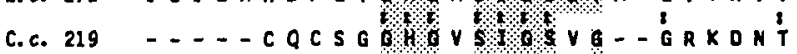

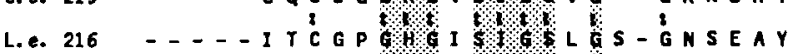

P.s. 309 VTDLTHDGND-SSAG HOYRTKSOASRGG

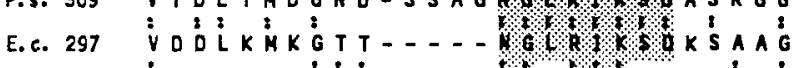
c.c. 240 VKGVVVSGTIIANSD L.e. 238 VSNITVNEAKIIGAE P.s. 336 KVTNIVYDGICMRNV-KEPLVFDPFYSS E.c. 320 VVNGVRYSNYVIK VAK-PIVIDTVYEK C.c. 268 SVSOITYENITLKNIAKYGIVIEQDYLN L.e. 266 QASNIKFLNVENQDV-KYPIIIOQNYCO

B

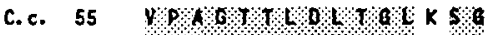

a. ก.

c.c. 96 N I K V V $\mathrm{OHSBH}$ I OAAG

A. ก. DIT

Figure 3. Sequence Similarity among Polygalacturonases from Bacteria, Fungi, and Plants.

(A) Comparison of portions of deduced amino acid sequences from four sequenced polygalacturonase genes. Three regions of anion and cation exchange chromatography (Walton and Cervone, 1990). Throughout the purification, the ratio of $P G$ activity determined by the reducing end group assay to PG activity determined by the viscometric assay remained constant in both SB111 and PG1. That is, after low-pressure cation exchange chromatography, preparations of PG1 had $10 \%$ as much PG activity as SB111 when determined viscometrically and $25 \%$ to $35 \%$ as much activity as SB111 when determined by the reducing end group assay. After step-gradient elution from the cation exchange column, the partially purified preparations were further resolved by high-pressure cation exchange chromatography, and PG activity in the fractions was measured by the reducing sugar assay. A broad peak with relatively low activity (the exoPG) was present in both strains, but the major peak of activity, corresponding to endoPG, was present in SB111 but missing in PG1, as shown in Figure 7.

Mutant strain PG1 and wild-type strain SB111 were spray-inoculated onto leaves of maize inbred K61, which is susceptible to infection by $C$. carbonum race 1 . The infected plants were examined daily for 6 days and no differences in lesion size, lesion number, or rate of disease development were observed. Leaves exhibiting typical symptoms are shown in Figure 8 . To confirm that strain PG1 retained the integrated plasmid while growing in vivo, isolates from several lesions were tested for hygromycin resistance. All 50 single-spored isolates from PG1-infected plants were hygromycin resistant and those from the wild type were hygromycin sensitive.

\section{DISCUSSION}

The fungal maize pathogen $C$. carbonum grows on pectin as sole carbon source and makes a substrate-inducible, catabolite-repressed endoPG (Walton and Cervone, 1990). The single gene ( $P G N 1$ ) encoding this enzyme has been cloned and its primary structure determined. Although the PGN1 gene was required for endoPG production, it was not necessary for either growth on pectin as sole carbon source or for pathogenicity on maize.

The ability of strain PG1 to grow on medium containing pectin as the sole carbon source demonstrates that $C$. carbonum must possess additional enzymatic activities

similarity mentioned in the text are shaded. Alignment was maximized by introducing gaps (-) or deleting regions with no similarity in the other three genes (-number of residues omitted-). P.s., Pseudomonas solanacearum (Huang and Schell, 1990); E.c., E. carotovora (S.-P. Lei and G. Wilcox, personal communication); C.c., C. carbonum (this work); L.e., Lycopersicon esculentum (Grierson et al., 1986).

(B) Two regions of sequence similarity between PGs from $C$. carbonum (C.C) and A. niger (A.n.). The A. niger sequences were obtained by amino acid sequencing of tryptic peptides. 
A

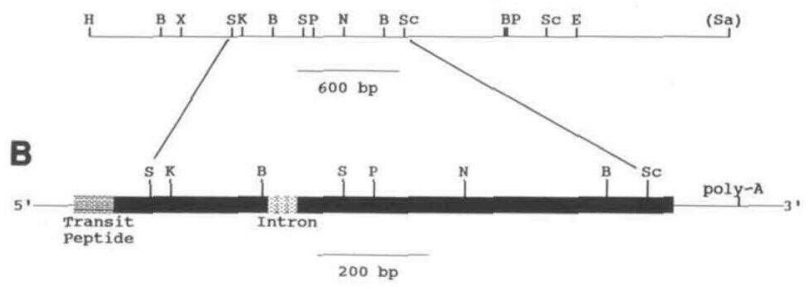

Figure 4. Restriction Map of PGN1 Genomic and CDNA Clones.

(A) Restriction map of 3.8-kb genomic clone containing the PGN1 gene.

(B) Restriction map of the 1.3-kb cDNA clone of PGN1 showing the location of the transit peptide, the single intron, and the polyadenylation site.

The Sall site (Sa) is derived from vector sequences. $\mathrm{B}, \mathrm{BamHl}$; , EcoRI; H, HindIII; K, Kpnl; N, Notl; P, Pstl; S, Stul; Sa, Sall; Sc, Sacl; X, Xbal.

capable of breaking down pectic polymers into metabolizable substrates. Although the peak of exoPG appeared small compared with endoPG (Figure 7), our culture and enzyme assay conditions were not optimized for exoPG production. Hence, C. carbonum might be capable of producing much higher levels of exoPG. The possible involvement of exoPG in maceration caused by a mutant of $E$. chrysanthemi lacking all five PL genes has been considered (Ried and Collmer, 1988). We hypothesize that the levels of exoPG made by mutant isolate PG1 are sufficient to support wild-type rates of growth on pectin.

Until now, genetic evidence for the involvement of endoPG in the fungal diseases of plants has relied on the analysis of chemically induced mutants. The availability of a cloned endoPG gene from $C$. carbonum has permitted the construction of a precise gene disruption mutant in which only the PG gene is affected. Because $C$. carbonum is haploid in its pathogenic phase and appears to contain only a single gene encoding endoPG, any changes in the phenotype of the mutant can be interpreted directly. Our results were consistent with the conclusions from the earlier studies, namely, that endoPG-minus fungal strains can still be effective pathogens.

The fact that mutant strain PG1 appeared to be unaffected in its ability to parasitize maize (Figure 8 ) demonstrated that endoPG is not an essential pathogenicity factor, at least in this host/pathogen interaction. There may be minor quantitative differences in the ability of PG1 and SB111 to colonize and reproduce in the host, but experiments that would detect small changes in parasitic fitness were not carried out. If degradation of pectic substances is required for pathogenicity, then the exoPG activity in PG1 would have to be sufficient because C. carbonum produces no PL (Nelson and Sherwood, 1968; J.D. Walton and F. Cervone, unpublished data). Alterna- tively, C. carbonum may be able to colonize tissue without degrading pectin. The lack of a role for endoPG in pathogenesis can be extended only with caution to other disease interactions, especially those involving dicotyledonous host plants that contain more pectin than monocotyledons, such as maize (Darvill et al., 1980). Our results also did not exclude the possible existence of other endoPGs that are induced only in vivo.

The active site of endoPG from $A$. niger contains $\mathrm{His}$ and a carboxylate-containing amino acid (Cooke et al., 1976; Rexova-Benkova and Mrackova, 1978). Within the regions that are highly conserved among the four endoPGs shown in Figure 3 , there is a single conserved $\mathrm{His}$ at position 225 and 2 conserved Asp residues at positions 204 and 205. Another conserved acidic residue (Asp or Glu) occurs at position 290 (Figure 3A). These amino acids are candidates for studies of endoPG action using sitespecific mutagenesis.

\section{METHODS}

\section{Fungal Culture and Enzyme Purification}

Cochliobolus carbonum race 1 isolate SB111, originally obtained from S. Briggs, Pioneer Hi-Bred International, Johnston, IA, was maintained and grown as described (Walton and Holden, 1988). EndoPG was purified from culture filtrates as described (Walton

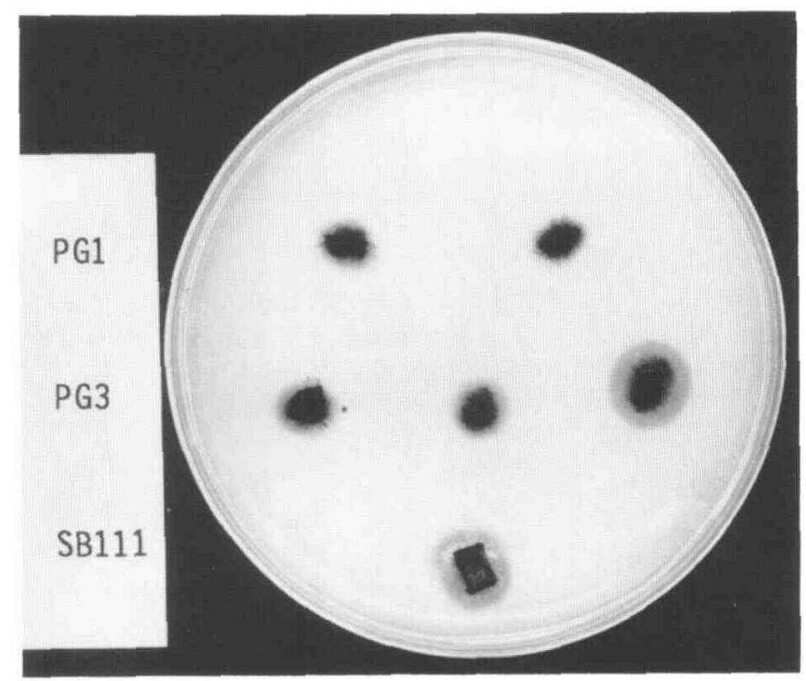

Figure 5. Plate Assay for PG Activity.

Five single-spored isolates from two transformants (PG1 and PG3) and one isolate from wild-type strain SB111 were grown on PGA agar for 6 days. The halos around the three PG3 and the wildtype isolates indicate the presence of PG activity and the absence of halos around the two PG1 isolates identifies them as lacking $P G$ activity. 


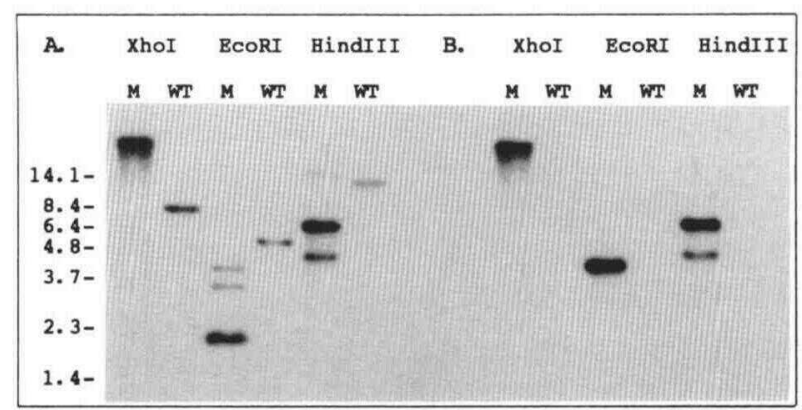

c. Wild-type

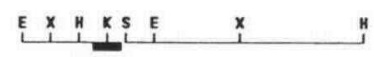

D. PG1

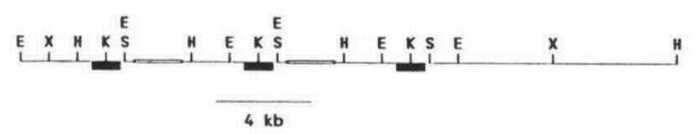

Figure 6. DNA Gel Blot of Total DNA from Wild-Type SB111 and EndoPG Mutant PG1.

(A) Probed with insert from plasmid pCC33. M, mutant; WT, wild type.

(B) Probed with pUC19. M, mutant; WT, wild type.

(C) Restriction map of the PGN1 gene region in wild-type strain SB111.

(D) Restriction map of the disrupted PGN1 gene in mutant strain PG1, assuming a double-tandem insertion event of pCC38.

The 854-bp fragment of the PGN1 gene contained in pCC33 (see Figure 4 ) is indicated by the thick lines in (C) and (D). The regions of DNA in PG1 that are derived from pUC19 are indicated by a double line in (C). E, EcoRl; H, Hindlll; K, Kpnl; S, Sacl; X, Xhol. Not all sites are shown.

and Cervone, 1990). The enzyme was cleaved with trypsin, and peptide fragments were separated on an HPLC C4 column (Vydac No. 214TP54) using a linear gradient of water $+0.1 \%$ TFA to $60 \%$ acetonitrile $+0.1 \%$ TFA in 60 min at a flow rate of $1 \mathrm{~mL} /$ min. Sequencing was done by automated Edman degradation at the Michigan State University Macromolecular Facility.

\section{Polygalacturonase Gene Isolation}

Three synthetic oligonucleotides were prepared based on amino acid sequence data. The $\mathrm{N}$-terminal amino acid sequence was DGCTFTDAATAIKNKA and the internal tryptic peptide sequence was YGIVIEQDYLNGGPTGKPTTG. Oligonucleotide 1 (5'-GAYGANTGYACNTTYACNGAYGC-3') is a 23-mer with 1024-fold degeneracy, $2\left(5^{\prime}\right.$-GCNATHAARAAYAARGC-3') is a $17-$ mer with 96-fold degeneracy, and 3 ( $5^{\prime}$-TARTCYTGYTCHATNAC-3') is a 17-mer with 96-fold degeneracy. ( $N$ indicates $A, T, C$, or $\mathrm{G}$; $Y$ indicates $\mathrm{T}$ or $\mathrm{C}$; $\mathrm{R}$ indicates $\mathrm{A}$ or $\mathrm{G}$; and $\mathrm{H}$ indicates $\mathrm{A}$, $\mathrm{T}$, or $\mathrm{C}$.) Oligonucleotides 1 and 3 were used as primers in the PCR with $100 \mathrm{ng}$ of $C$. carbonum genomic DNA as template. The reactions were carried out in a Perkin-Elmer Cetus DNA Thermal Cycler
(Perkin-Elmer Corp., Norwalk, CT) using AmpliTaq DNA polymerase (Perkin-Elmer Cetus) for 25 cycles (one cycle $=1 \mathrm{~min}$ at $94^{\circ} \mathrm{C}, 2 \mathrm{~min}$ at $46^{\circ} \mathrm{C}$, and $3 \mathrm{~min}$ at $72^{\circ} \mathrm{C}$ ) according to the manufacturer's instructions. The products of the reaction were size fractionated on an agarose gel, blotted onto nitrocellulose, and probed with radiolabeled internal oligonucleotide 2. An 854bp PCR product that hybridized to oligonucleotide 2 was bluntend ligated into the phagemid vector Bluescript+ (Stratagene, La Jolla, CA) and used as a probe to screen both genomic and CDNA
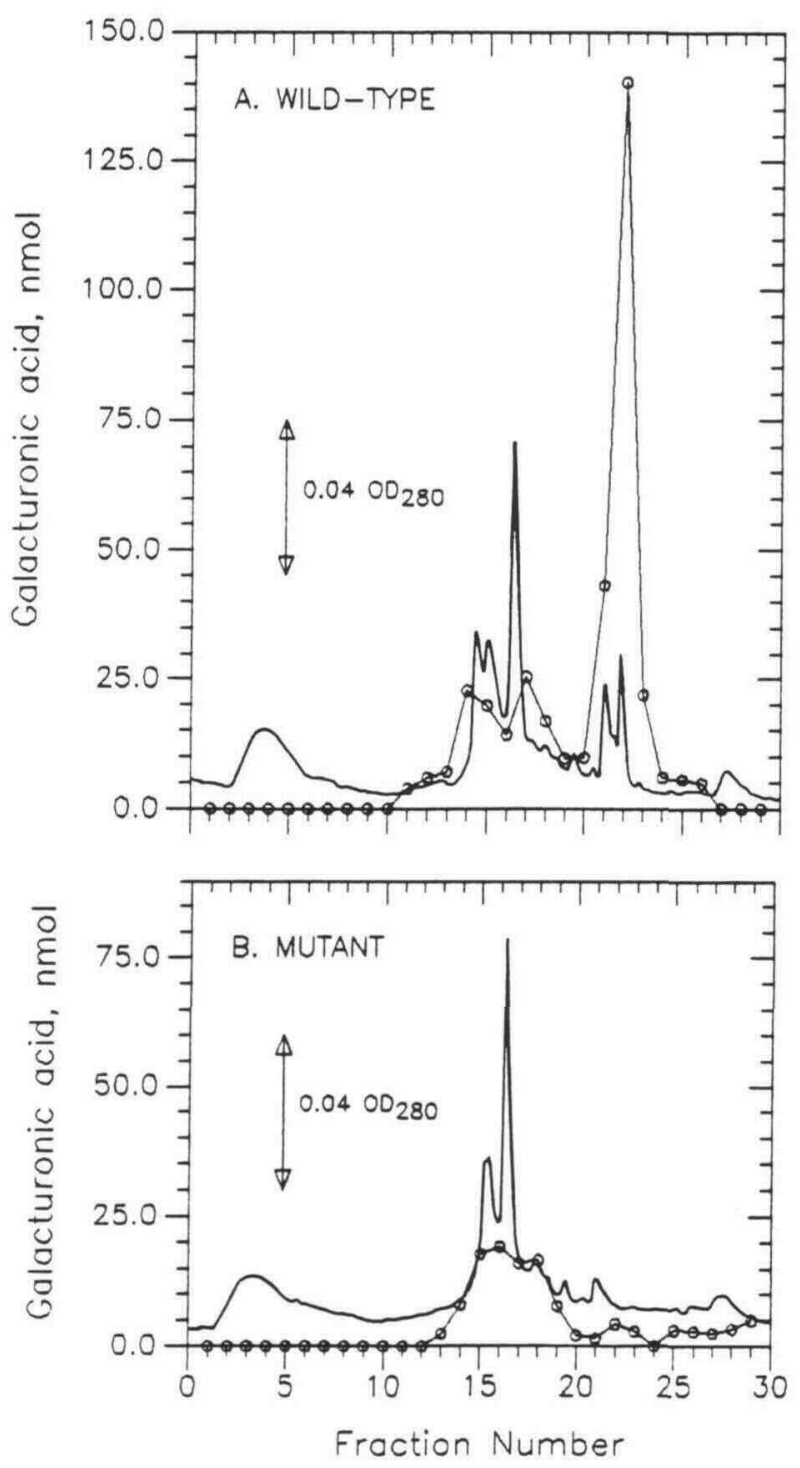

Figure 7. Characterization of PG Activities by Cation Exchange HPLC.

(A) Enzyme activity (circles) in wild-type strain SB111 was measured by the reducing sugar assay with PGA as substrate. The solid line is absorbance at $280 \mathrm{~nm}$.

(B) Enzyme activity in mutant strain PG1. 


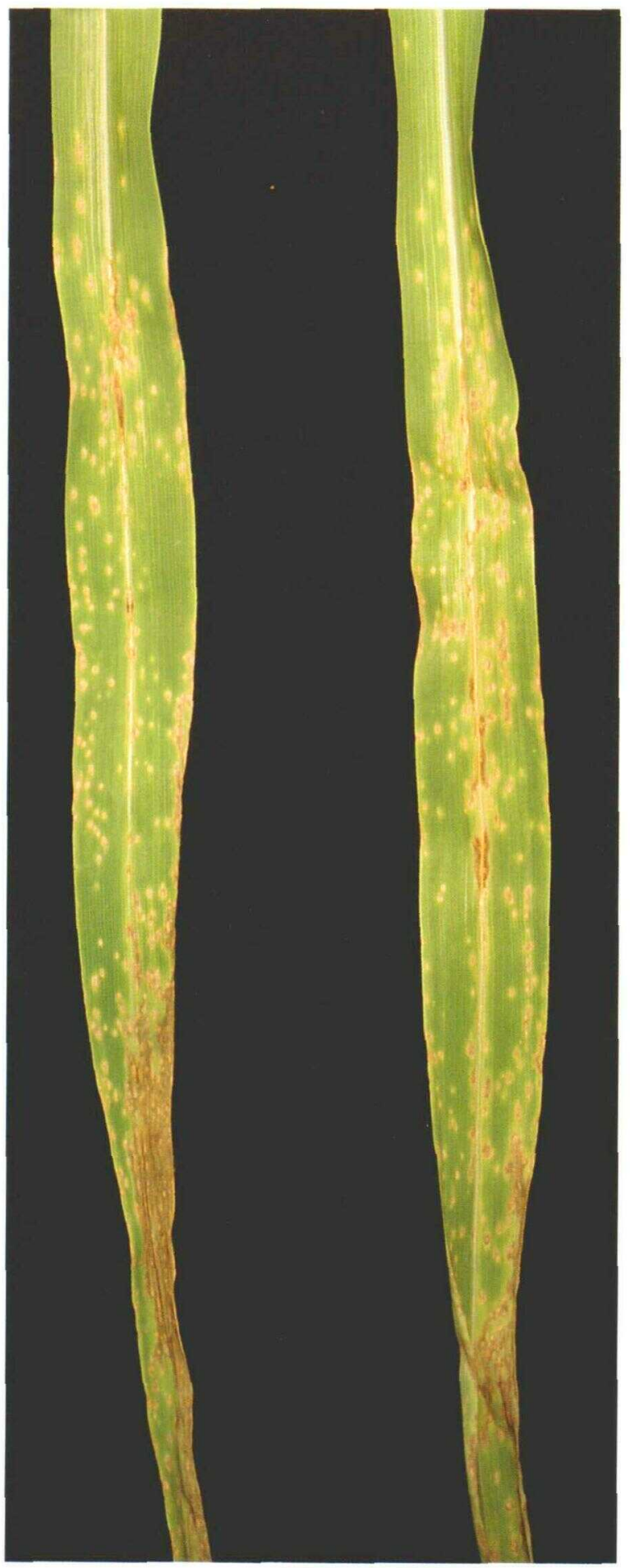

Figure 8. Infection Phenotype of Maize Leaves Inoculated with C. carbonum Wild-Type Strain SB111 and Mutant Strain PG1.

Fourteen-day-old maize plants were spray-inoculated with a spore suspension $\left(5 \times 10^{4}\right.$ spores $\left./ \mathrm{mL}\right)$ of $C$. carbonum wild-type strain libraries. Hybridizing plaques were identified and their inserts subcloned by standard methods (Maniatis et al., 1982).

\section{Nucleic Acid Manipulations}

DNA and poly $(A)^{+}$RNA were isolated from $C$. carbonum mycelium by the method of Yoder (1988). A genomic DNA library was constructed in the bacteriophage vector $\lambda$ EMBL3 by standard methods (Maniatis et al., 1982). cDNA was synthesized from poly $(A)^{+}$RNA using a Lambda Librarian kit (Invitrogen, San Diego, $\mathrm{CA})$ and used to construct a library in bacteriophage $\lambda$-vector gt10. Both libraries were packaged in vitro using Gigapack Gold Packaging Extracts (Stratagene) according to the manufacturer's instructions. For RNA gel blot analysis, poly(A) ${ }^{+}$RNA was isolated from $C$. carbonum grown on $1 \%$ pectin or $2 \%$ sucrose as carbon source (Yoder, 1988). The poly $(A)^{+}$RNA was fractionated on a formaldehyde agarose gel, transferred to nitrocellulose, and probed with a radiolabeled internal fragment of the PG gene as described (Ausubel et al., 1987). For DNA gel blot analysis, total genomic DNA from $C$. carbonum was restricted with endonucleases, fractionated on an agarose gel, and transferred to nitrocellulose (Maniatis et al., 1982). The filter was hybridized with a radiolabeled probe and washed as described in Adams et al. (1984).

\section{DNA Sequencing}

A series of nested deletions was prepared using the exonuclease III/mung bean nuclease protocol described by Stratagene. Singlestranded DNA templates were purified by the method of Dente et al. (1983). DNA was sequenced with Sequenase and the dideoxynucleotide method (United States Biochemicals, Cleveland, $\mathrm{OH}$ ). The sequence data were computer analyzed with the DNASIS and PROSIS programs (Hitachi Software Engineering Co., San Bruno, CA).

\section{Transformation-Mediated Gene Disruption}

An internal 944-bp Kpnl/Sacl fragment of the PGN1 gene was cloned into the shuttle vector pUCHI (Schafer et al., 1989) and the resultant plasmid (pCc38) used to transform $C$. carbonum strain SB111 to hygromycin resistance. Frozen stock cultures of the fungus were inoculated onto V8 juice agar plates (Stevens, 1974) and conidia were collected after 7 days by several washes with sterile water. The conidia were used to inoculate $500 \mathrm{~mL}$ of modified Fries' medium (Walton and Cervone, 1990) and grown for $14 \mathrm{hr}$ at $30^{\circ} \mathrm{C}$ in a gyratory shaker at $250 \mathrm{rpm}$.

Protoplasts were prepared from the resultant mycelia as described by Panaccione et al. (1988) except that cell walls were digested with chitinase (Sigma C-1650) at $25 \mu \mathrm{g} / \mathrm{mL}$ and Driselase (Sigma D-9515) at $10 \mathrm{mg} / \mathrm{mL}$ in addition to Novozyme 234 (Novo Laboratories, Wilton, CT) at $10 \mathrm{mg} / \mathrm{mL}$. The transformation protocol was derived from those developed for Cochliobolus heterostrophus (Turgeon et al., 1987) and Aspergillus nidulans (Oakley

SB111 (left) or mutant strain PG1 (right). Leaves showing typical symptoms were photographed 6 days after infection. 
et al., 1987). Plasmid pCC38 (4 $\mu \mathrm{g}$ at $1 \mu \mathrm{g} / \mu \mathrm{L})$ that had been linearized at an internal Notl site was added to $2 \mu \mathrm{L}$ of $50 \mu \mathrm{M}$ spermidine and $5 \mu \mathrm{L}$ of $2.5 \mathrm{mg} / \mathrm{rnL}$ heparin and incubated on ice for $30 \mathrm{~min}$. Protoplasts $\left(5 \times 10^{6}\right)$ in $100 \mu \mathrm{L}$ of $1.0 \mathrm{M}$ sorbitol, 50 $\mathrm{mM}$ Tris- $\mathrm{Cl}, \mathrm{pH} 8.0$, and $50 \mathrm{mM} \overline{\mathrm{CaCl}}_{2}$ were added to the DNA solution and incubated on ice for $30 \mathrm{~min}$. One milliliter of $P E G$ solution (25\% PEG $8000,0.6 \mathrm{M} \mathrm{KCl}, 50 \mathrm{mM}$ Tris-Cl, pH 8.0, 50 $\mathrm{mM} \mathrm{CaCl}{ }_{2}$ ) was added, mixed gently, and incubated at ambient temperature for $20 \mathrm{~min}$. The protoplast solution was placed in a $100-\mathrm{mm}$ Petri dish, mixed with $20 \mathrm{~mL}$ of plating medium (1 M sucrose, $0.1 \%$ tryptone, $0.1 \%$ yeast extract, $0.7 \%$ agarose) and incubated at $30^{\circ} \mathrm{C}$ for $6 \mathrm{hr}$. The plates were then overlaid with 10 $\mathrm{mL}$ of plating medium containing hygromycin $\mathrm{B}$ at $150 \mu \mathrm{g} / \mathrm{mL}$ (Behring Diagnostics, La Jolla, CA) and incubated at $30^{\circ} \mathrm{C}$ for 5 days to 10 days.

\section{PG Disruption Mutant Analysis}

Transformants were purified to nuclear homogeneity by two rounds of single-sporing and then screened for the ability to digest PGA. Plugs of mycelium were placed on plates containing PGA medium [5 $\mathrm{g}$ of PGA (Sigma P-1879), $2 \mathrm{~g}$ of sucrose, $2 \mathrm{~g}$ of $\left(\mathrm{NH}_{4}\right)_{2} \mathrm{SO}_{4}$, and $15 \mathrm{~g}$ of agar per liter] and incubated at $30^{\circ} \mathrm{C}$. After 2 days to 4 days, the plates were flooded with $5 \mathrm{~mL}$ of 0.4 $\mathrm{N} \mathrm{HCl}$ for $10 \mathrm{~min}$ and then washed several times with sterile water. The absence of a distinct halo around the fungal colony indicated that the ability to digest PGA had been lost. Culture filtrates of mutant isolate PG1 and wild-type isolate SB111 were compared for the ability to degrade P.GA by both viscometric and reducing sugar assays (Walton and Cervone, 1990). PG was partially purified from both culture filtrates by DEAE-cellulose chromatography as described by Walton and Cervone (1990). These preparations were used to digest PGA and the end products examined by thin layer chromatography (Zink and Chatterjee, 1985). PG from both isolates was further purified by cation exchange chromatography (Walton and Cervone, 1990) and the PG activity of each fraction was measured by the reducing sugar assay.

For pathogenicity tests, maize inbred $K 61$ (susceptible to $C$. carbonum race 1) was inoculated with conidial suspensions $\left(10^{4} /\right.$ $\mathrm{mL}$ ). The infection phenotype was scored daily. Several leaf segments from plants infected with each strain were cut out, surface sterilized, and placed on V8 juice agar plates. From the resultant fungal mats, 50 single-conidial isolates were obtained and tested for their ability to grow on V8 juice agar amended with $100 \mu \mathrm{g} / \mathrm{mL}$ hygromycin B.

\section{ACKNOWLEDGMENTS}

We thank Joseph Leykam, Michigan State University Macromolecular Facility, for the amino acid sequencing and oligonucleotide synthesis; and Alan Collmer, Cornell University; Shau-Ping Lei and Gary Wilcox, XOMA Corp., Santa Monica, CA; and Mark Schell, University of Georgia, for sharing sequence data before publication. We also thank Guilia De Lorenzo and Eugenia Schinina, University of Rome, for the A. niger PG sequences. This research was supported by the National Science Foundation (DMB 87-
15608), the NATO Collaborative Research program (0449/88), and the U.S. Department of Energy Division of Biological Energy Research under Contract DE-AC02-76ER01338.

The nucleotide sequence data reported in this paper will appear in the EMBL, GenBank, and DDJB Nucleotide Sequence Databases under accession number M37819.

Received August 20, 1990; accepted October 8, 1990.

\section{REFERENCES}

Adams, T.H., McClung, C.R., and Chelm, B.K. (1984). Physical organization of the Bradyrhizobium japonicum nitrogenase gene region. J. Bacteriol. 159, 857-862.

Anderson, A.J. (1978). Extracellular enzymes produced by Colletotrichum lindemuthianum and Helminthosporium maydis during growth on isolated bean and corn cell walls. Phytopathology 68, 1585-1589.

Ausubel, F.M., Brent, R., Kingston, R.E., Moore, D.D., Seidman, J.G., Smith, J.A., and Struhl, K. (1987). Current Protocols in Molecular Biology. (New York: John Wiley \& Sons).

Bateman, D.F., and Basham, H.G. (1976). Degradation of plant cell walls and membranes by microbial enzymes. In Encyclopedia of Plant Physiology New Series, Vol. 4, Physiological Plant Pathology, R. Heitefuss and P.H. Williams, eds (New York: Springer-Verlag), pp. 316-355.

Bishop, P.D., Pearce, G., Bryant, J.E., and Ryan, C.A. (1984). Isolation and characterization of the proteinase inhibitor-inducing factor from tomato leaves. Identity and activity of polyand oligo-galacturonide fragments. J. Biol. Chem. 259, 13172-13177.

Boccara, M., and Chatain, V. (1989). Regulation and role in pathogenicity of Erwinia chrysanthemi 3937 pectin methylesterase. J. Bacteriol. 171, 4085-4087.

Cervone, F., De Lorenzo, G., Degra, L., and Salvi, G. (1987). Elicitation of necrosis in Vigna unguiculata Walp. by homogeneous Aspergillus niger endo-polygalacturonase and by $\alpha$-D-galacturonate oligomers. Plant Physiol. 85, 626-630.

Cervone, F., Hahn, M.G., De Lorenzo, G., Darvill, A., and Albersheim, P. (1989). Host-pathogen interactions. XXXIII. A plant protein converts a fungal pathogenesis factor into an elicitor of plant defense responses. Plant Physiol. 90, 542-548.

Collmer, A., and Keen, N.T. (1986). The role of pectic enzymes in plant pathogenesis. Annu. Rev. Phytopathol. 24, 383-409.

Cooke, R.D., Ferber, C.E.M., and Kanagasabapathy, L. (1976). Purification and characterisation of polygalacturonases from a commercial Aspergillus niger preparation. Biochim. Biophys. Acta 452, 440-451.

Cooper, R.M. (1984). The role of cell wall-degrading enzymes in infection and damage. In Plant Diseases: Infection, Damage and Loss, R.K.S. Wood and G.J. Jellis, eds (Oxford: Blackwell Scientific Publications), pp. 13-27. 
Darvill, A., MeNeil, M., Albersheim, P., and Delmer, D.P. (1980). The primary cell walls of flowering plants. In The Biochemistry of Plants, Vol. 1, P.K. Stumpf and E.E. Conn, eds (New York: Academic Press), pp. 91-162.

Davis, K.R., Lyon, G.D., Darvill, A.G., and Albersheim, P. (1984). Host-pathogen interactions. XXV. Endopolygalacturonic acid lyase from Erwinia carotovora elicits phytoalexin accumulation by releasing plant cell wall fragments. Plant Physiol. 74, 52-60.

Dean, R.A., and Timberlake, W.E. (1989). Regulation of the Aspergillus nidulans pectate lyase gene (pelA). Plant Cell 1, 275-284.

Dente, L., Cesareni, G., and Cortese, R. (1983). pEMBL: A new family of single stranded plasmids. Nucl. Acids Res. 11, 1645-1655.

Dow, J.M., Milligan, D.E., Jamieson, L., Barber, C.E., and Daniels, M.J. (1989). Molecular cloning of a polygalacturonate lyase gene from Xanthomonas campestris pv. campestris and role of the gene product in pathogenicity. Physiol. Mol. Plant Pathol. 35, 113-120.

Durrands, P.K., and Cooper, R.M. (1988). The role of pectinases in vascular wilt disease as determined by defined mutants of Verticillium albo-atrum. Physiol. Mol. Plant Pathol. 32, 363-371.

English, P.D., Maglothin, A., Keegstra, K., and Albersheim, P. (1972). A cell wall-degrading endopolygalacturonase secreted by Colletotrichum lindemuthianum. Plant Physiol. 49, 293-297.

Fincham, J.R.S. (1989). Transformation in fungi. Microbiol. Rev. 53, 148-170.

Grierson, D., Tucker, G.A., Keen, J., Ray, J., Bird, C.R., and Schuch, W. (1986). Sequencing and identification of a CDNA clone for tomato polygalacturonase. Nucl. Acids Res. 14, 8595-8603.

Gysler, C., Harmsen, J.A.M., Kester, H.M.C., Visser, J., and Heim, J. (1990). Isolation and structure of the pectin lyase Dencoding gene from Aspergillus niger. Gene 89, 101-108.

Hahn, M.G., Bucheli, P., Cervone, F., Doares, S.H., O'Neill, R.A., Darvill, A., and Albersheim, P. (1989). Roles of cell wall constituents in plant-pathogen interactions. In Plant-Microbe Interactions, Vol. 3, T. Kosuge and E.W. Nester, eds (New York: McGraw-Hill), pp. 131-181.

He, S.Y., and Colimer, A. (1990). Molecular cloning, nucleotide sequence, and marker exchange mutagenesis of the exo-poly$\alpha$-D-galacturonosidase-encoding pehX gene of Erwinia chrysanthemi EC16. J. Bacteriol. 172, 4988-4995.

Hinton, J.C.D., Gill, D.R., Lalo, D., Plastow, G.S., and Salmond, G.P.C. (1990). Sequence of the peh gene of Erwinia carotovora: Homology between Erwinia and plant enzymes. Mol. Microbiol. 4, 1029-1036.

Howell, H.E. (1975). Correlation of virulence with secretion in vitro of three wall-degrading enzymes in isolates of Sclerotinia fructigena obtained after mutagen treatment. J. Gen. Microbiol. 90, $32-40$.

Huang, J., and Schell, M.A. (1990). DNA sequence analysis of pglA and mechanism of export of its polygalacturonase product from Pseudomonas solanacearum. J. Bacteriol. 172, 3879-3887.

Karr, A.L., and Albersheim, P. (1970). Polysaccharide-degrading enzymes are unable to attack plant cell walls without prior action by a "wall-modifying enzyme." Plant Physiol. 46, 69-80.
Lee, S.-C., and West, C. (1981). Polygalacturonase from Rhizopus stolonifer, an elicitor of casbene synthetase activity in castor bean (Ricinus communis L.). Plant Physiol. 67, 633-639.

Maniatis, T., Fritsch, E.F., and Sambrook, J. (1982). Molecular Cloning: A Laboratory Manual. (Cold Spring Harbor, NY: Cold Spring Harbor Laboratory).

Mann, B. (1962). Role of pectic enzymes in the Fusarium wilt syndrome of tomato. Trans. Br. Mycol. Soc. 45, 169-178.

Nelson, R.R., and Sherwood, R.T. (1968). Genetic control of endopolygalacturonase production in Cochliobolus carbonum. Phytopathology 58, 1277-1280.

Oakley, B.R., Rinehart, J.E., Mitchell, B.L., Oakley, C.E., Carmona, C., Gray, G.L., and May, G.S. (1987). Cloning, mapping and molecular analysis of the pyrG (orotidine-5'-phosphate decarboxylase) gene of Aspergillus nidulans. Gene 61, 385-399.

Orbach, M.J., Porro, E.B., and Yanofsky, C. (1986). Cloning and characterization of the gene for beta-tubulin from a benomylresistant mutant of Neurospora crassa and its use as a dominant selectable marker. Mol. Cell. Biol. 6, 2452-2461.

Panaccione, D.G., McKiernan, M., and Hanau, R.M. (1988). Colletotrichum graminicola transformed with homologous and heterologous benomyl-resistance genes retains expected pathogenicity to corn. Mol. Plant-Microbe Interact. 1, 113-120.

Plastow, G.S. (1988). Molecular cloning and nucleotide sequence of the pectin methyl esterase gene of Erwinia chrysanthemi B374. Mol. Microbiol. 2, 247-254.

Puhalla, J.E., and Howell, C.R. (1975). Significance of endopolygalacturonase activity to symptom expression of verticillium wilt in cotton, assessed by the use of mutants of Verticillium dahliae Kleb. Physiol. Plant Pathol. 7, 147-152.

Rexova-Benkova, L., and Mrackova, M. (1978). Active groups of extracellular endo-D-galacturonase of Aspergillus niger derived from $\mathrm{pH}$ effect on kinetic data. Biochim. Biophys. Acta 523, 162-169.

Ried, J.L., and Collmer, A. (1988). Construction and characterization of an Erwinia chrysanthemi mutant with directed deletions in all of the pectate lyase structural genes. Mol. PlantMicrobe Interact. 1, 32-38.

Schafer, W., Straney, D., Cuiffetti, L., Van Etten, H.D., and Yoder, O.C. (1989). One enzyme makes a fungal pathogen, but not a saprophyte, virulent on a new host plant. Science 246, 247-249.

Stevens, R.B. (1974). Mycology Guidebook. (Seattle: University of Washington Press), p. 665.

Turgeon, B.G., Garber, R.C., and Yoder, O.C. (1987). Development of a fungal transformation system based on selection of sequences with promoter activity. Mol. Cell. Biol. 7, 3297-3305.

von Heijne, G. (1986). A new method for predicting signal sequence cleavage sites. Nucl. Acids Res. 14, 4683-4690.

Walton, J.D., and Cervone, F. (1990). Endopolygalacturonase from the maize pathogen Cochliobolus carbonum. Physiol. Mol. Plant Pathol. 36, 351-359.

Walton, J.D., and Holden, F.R. (1988). Properties of two enzymes involved in the biosynthesis of the fungal pathogenicity factor 
HC-toxin. Mol. Plant-Microbe Interact. 1, 128-134.

Yoder, 0.C. (1988). Cochliobolus heterostrophus, cause of southern corn leaf blight. Adv. Plant Pathol. 6, 93-112.

Zink, R.T., and Chatterjee, A.K. (1985). Cloning and expression in Escherichia coli of pectinase genes of Erwinia carotovora subsp. carotovora. Appl. Environ. Microbiol. 49, 714-717. 